5. Дюгі Л. Конституційне право: Загальна теорія держави. Репринт / Передмова Ю.М. Оборотова. Одеса: Юридична література, 2005. 1008 с.

6. Паламарчук В. Теоретико-правові основи розуміння державної території України. Підприсмництво, господарство і право. 2017. № 1. C. $182-186$.

7. Шкабаро В.М., Ященко В.М. Територія як ключова ознака держави та іiі характеристики. Вісник Дніпропетровського університету імені Альфреда Нобеля. Серія «Юридична науки». 2015. № 2(7). С. 56-61.

DOI https://doi.org/10.30525/978-9934-588-92-1-7

\title{
ІСТОРИКО-ПРАВОВІ АСПЕКТИ ФОРМУВАННЯ СПЕЦІАЛЬНОГО ЗАКОНОДАВСТВА У СФЕРІ НАЦІОНАЛЬНОЇ БЕЗПЕКИ УКРАЇНИ
}

\author{
Доронін І. М. \\ кандидат юридични наук, дочент, \\ завідувач науково-дослідної лабораторії \\ Науково-дослідного інституту інформатики і права \\ Національної академії правових наук України \\ м. Київ, Украӥна
}

Становлення законодавства у сфері національної безпеки та оборони в Україні розвивалось за певними періодами, що включає відповідний етап, який характеризує організацію та впровадження відповідної моделі забезпечення національної безпеки. Мова йде про ухвалення уперше спеціального законодавчого акту в цій сфері - Закону України «Про основи національної безпеки в Україні» від 19.06.2003 p.

Підгрунтям для ухвалення законодавчого акту були вимоги реформування системи забезпечення національної безпеки, що випливали із прийняттям Конституції України та побудовою відповідної системи державної влади на основі конституційних приписів. До цього часу організація системи забезпечення національної безпеки України грунтувалась на положеннях Концепції (основ державної політики), схваленою постановою Верховної Ради України від 16.01.1997 р. № 3/97. Зазначений акт відображав відповідні стратегічні настанови, що були в подальшому реалізовані у побудові відповідної організаційно-правової моделі. Насамперед мова йшла про 
загальну структуру уявлень, стратегічні цілі та відповідні підходи до формування системи. Цілі іiї схвалення були сформульовані як потреба у єдності принципів формування та реалізації державної політики національної безпеки, а також поєднанні підходів до планування у цій сфері та ухвалення відповідної законодавчої бази.

Концепцією визначався понятійний апарат у сфері національної безпеки i регламентувались найбільш важливі аспекти системи національної безпеки. Зокрема, у Концепції було надано визначення національної безпеки як стану захищеності життєво важливих інтересів особи, суспільства та держави від внутрішніх та зовнішніх загроз. Окрім цього, визначались об'єкти та принципи національної безпеки, національні інтереси України. Надавалось визначення загрозам національній безпеці України у відповідних сферах. Відповідним чином деталізувались і напрями державної політики, які відповіді на такі загрози.

У подальшому, враховуючи, що стан забезпечення національної безпеки підлягає періодичному перегляду, було запропоновано оновити Концепцію національної безпеки. Так, у пояснювальній записці до законопроекту 2062 від 13.08.2002 р., підготовленого на виконання рішення Ради національної безпеки і оборони України від 12 червня 2002 року «Про нову редакцію Концепції національної безпеки України», було констатовано, що за п'ять 3 половиною років після схвалення Концепції суттєво змінилася і внутрішня, i зовнішня геополітична ситуація. Зазначений висновок ініціатором законопроекту конкретизований не був. Водночас, слід зауважити, що Президент України пропонував ухвалити Законом України нову редакцію Концепції національної безпеки, попри на рекомендаційний характер положень Концепції, що випливав з пунктів 2 та 3 постанови Верховної Ради України від 16.01.1997 р. № 3/97.

На етапі обговорення поданого Президентом України проекту відбулась певна зміна позиції щодо характеру правової регламентації забезпечення національної безпеки. Зокрема, пунктом 17 статті 92 Конституції України передбачено, що основи національної безпеки мають визначатися виключно законом України. Унаслідок обговорення було враховано поправки народного депутата Г.М. Манчуленка, які фактично стосувались змін у формі правової регламентації - від Концепції до Закону України «Про основи національної безпеки України».

Розгляд законопроекту у Верховній Раді України тривав біля року, внаслідок чого 19 червня 2003 року його було ухвалено як Закон України «Про основи національної безпеки». Одночасно з ним було 38 
прийнято Закон України «Про демократичний цивільний контроль над Воєнною організацією i правоохоронними органами держави». Зазначені закони тривалий час складали основу спеціального законодавства у сфері національної безпеки.

Оскільки призначення Закону України «Про основи національної безпеки» полягало у визначенні основних засад державної політики, спрямованої на захист національних інтересів і гарантування в Україні безпеки особи, суспільства і держави від зовнішніх і внутрішніх загроз в усіх сферах життєдіяльності, він сформував відповідну систему забезпечення національної безпеки. В основі цієї системи можливо виокремити відповідну організаційно-правову модель, яка характеризується низкою властивостей.

У першу чергу мова йде про суб'єктний склад, який утворює певну систему. До числа суб'єктів законодавець відніс доволі велике коло, що включало Президента України, Верховну Раду України, Кабінет Міністрів України, Раду національної безпеки і оборони України, центральні органи виконавчої влади, Національний банк України, суди загальної юрисдикції, прокуратура, місцеві державні адміністрації та органи місцевого самоврядування. Зазначені суб'єкти мали чітко визначений статус у системі державної влади відповідно до ії поділу (крім прокуратури). Окрім цього до числа суб'єктів було віднесено Збройні Сили України, Службу безпеки України, Державну прикордонну служба України та інші військові формування, утворені відповідно до законів України, а також громадян України та об'єднання громадян. Зазначене законодавче трактування суб'єктів забезпечення національної безпеки було зумовлено як особливою роллю Військової організації серед суб'єктів так і своєрідною законодавчою регламентацією, яка було зумовлена наявністю відповідних прогалин щодо правового статусу військових формувань, окремі з яких неврегульовані досі.

Іншою властивістю $є$ наділення суб'єктів відповідним обсягом повноважень щодо виконання визначених для них завдань, що мало відбуватись шляхом розробки та ухвалення спеціальних законодавчих актів. Зазначене положення було обумовлено наявністю відповідних законодавчих приписів у ст. 9 і 10 Закону України «Про основи національної безпеки України». Частина приписів дублювала положення чинної Конституції України, інша частина - стосувалась визначення основних напрямів діяльності, що вимагали належної регламентації на рівні спеціальних законодавчих актів. Так для центральних органів виконавчої влади було передбачено забезпечення виконання передбачених Конституцією і законами України, а також актами законодавства, завдань; здійснення реалізації концепцій та 
інших документів стратегічного планування; підтримання у стані готовності до застосування сил та засобів забезпечення національної безпеки. Слід зазначити доволі побіжну регламентацію обсягів повноважень для органів державної влади на місцях, оскільки відсилочна по суті норма стосовно забезпечення «вирішення питань» відповідно до компетенції на той час не уточнювала завдання та обсяг повноважень для цих органів.

Окремо слід вказати на наявність змін у підходах щодо ролі і місця громадян України у забезпеченні національної безпеки, оскільки Концепція однозначно визначала народ України суб'єктом забезпечення національної безпеки. Закон України «Про основи національної безпеки України» для громадян України встановлював опосередкований механізм - через участь у виборах, референдумах та інших формах безпосередньої демократії, а також через органи державної влади та органи місцевого самоврядування. Окрім цього Законом передбачалось, що громадяни як безпосередньо, так і через об'єднання громадян, привертають увагу суспільних і державних інститутів до небезпечних явищ i процесів у різних сферах життєдіяльності країни, а також у законний спосіб і законними засобами захищають власні права та інтереси, а також власну безпеку.

Функціональний аспект системи характеризувався наявністю законодавчих приписів стосовно обсягу основних функцій суб'єктів забезпечення національної безпеки, розподіл яких між ними безпосередньо у Законі України «Про основи національної безпеки України» передбачений не був. Подальша законодавча регламентація на цьому рівні також проведена не була, а тому відповідні прогалини залишались неврегульованими до початку агресії проти України, i лише частково виправленими у період оновлення законодавства у сфері національної безпеки у 2018 році.

Окрім цього, до негативних факторів впливу на подальший розвиток законодавства у сфері національної безпеки можливо віднести зміну в політичних пріоритетах, нечітке ставлення до військово-політичних союзів та загалом до систем міжнародної безпеки, а також намагання змінити саме розуміння феномену «національної безпеки», що яскраво може бути проілюстрована змінами до Закону України «Про основи національної безпеки України», які було внесено низкою законодавчих актів, у першу чергу внаслідок прийняття Закону України «Про засади внутрішньої і зовнішньої політики» від 01.07.2010 р. № 2411-VI.

Таким чином, зазначене вище дозволяе прийти до висновку, що формування спеціального законодавства у сфері національної безпеки відбувалось шляхом прийняття у 2003 році спеціальних законодавчих 40 
актів, які регламентували суспільні відносини у цій сфері, встановлювали відповідну організаційно-правову модель, завдання для іiі суб'єктів та наділяли державні органи відповідним обсягом повноважень. Водночас, подальша імплементація положень спеціальних законодавчих актів у відповідне законодавство у повному обсязі проведена не була, що зумовлювалось зміною політичних пріоритетів, насамперед унаслідок діяльності п'ятої коаліції 6-го скликання Верховної Ради України і результатів президентських виборів 2010 року.

DOI https://doi.org/10.30525/978-9934-588-92-1-8

\title{
ДЕРЖАВНО-ПРАВОВА ІДЕОЛОГІЯ МОНГОЛЬСЬКОЇ ІМПЕРІЇ (1206-1279) ЯК ПРЕДТЕЧА РОСІЙСЬКОГО ЕКСПАНСІОНІЗМУ
}

\author{
Іванов О. Ю. \\ кандидат юридичних наук, \\ старший викладач кафедри теорії та історії держави і права \\ Національної академії Служби безпеки України \\ м. Київ, Украӥна
}

Невід'ємною ознакою розвитку сучасного міжнародного правопорядку є його глобалізація. У зв'язку з цим на стан його забезпечення безпосередньо впливають особливості правової ідеології та політики в окремих регіонах. Останні спрямовані головним чином на забезпечення міжнародної безпеки, проте в окремих випадках виступають i джерелами формування викликів для неї. 3-поміж них одне із найважливіших місць посідає Російська Федерація (далі - РФ) зі своєю агресивною зовнішньою політикою, котра, серед іншого, безпосередньо загрожує реалізації національних інтересів нашої держави. Геополітичний курс РФ базується на ідеологічних постулатах, що мають глибоке історичне коріння і були характерними ще для Московського царства, Російської імперії та радянської Росії. Виходячи 3 цього, для цілісного розуміння сучасної ситуації, особливо в контексті оцінки російського фактора в парадигмі забезпечення державної безпеки України, доцільним видається висвітлення історико-правових аспектів формування зовнішньої політики РФ.

Історія свідчить, що становлення експансіоністських основ російської державницької ідеології пов'язано з оформленням концепції 